\title{
Aplikasi Panduan Pola Hidup Sehat
}

\author{
Afit Muhammad Lukman', Oki Rahmanto² \\ ${ }^{1}$ Sistem Informasi, Fakultas Teknik dan Informatika (Universitas Bina Sarana Informatika) \\ ${ }^{2}$ Teknolgi Komputer, Fakultas Teknik dan Informatika (Universitas Bina Sarana Informatika) \\ 1afit.fml@bsi.ac.id, 20kirahmanto96@gmail.com
}

\begin{abstract}
Various applications are created to facilitate human activities. Many things can be done only with cell phones, ranging from communication to entertainment, management, multimedia, and others. Every cell phone has an operating system to run application programs. Based on data from IDC (International Data Corparation) shows that the smartphone market worldwide grew 27.2\% in 2014 with 335 million units of devices. Delivery of Android devices ranks first in world market with 283 million units of devices shipped and more than 84\% market share in the third quarter of 2014. This is due to increased consumer demand. This shows that android is in demand by users all over the world. This factor is the reason for creating applications on the Android platform. In this study, researchers will make a healthy lifestyle guide application for mobile devices, especially smartphones based on Android. So that only by using a smartphone, users can make it easier to do a healthy lifestyle and regulate calorie intake without buying books or consulting a health professional. This of course can be a tool in managing healthy lifestyles. The steps taken to carry out the application development process include the stages of problem and needs analysis, application design and interface design, so that the application formed becomes easy to use. From the trial results it is proven that the application of a healthy lifestyle can provide information and convenience to some people in managing their lifestyle.
\end{abstract}

Keywords: Android, a healthy lifestyle, a smartphone.

Abstrak - Beragam aplikasi diciptakan untuk memudahkan aktifitas manusia. Banyak hal yang dapat dilakukan hanya dengan telepon seluler, mulai dari komunikasi sarana hiburan, manajemen, multimedia, dan lainnya. Setiap telepon seluler memiliki sistem operasi untuk menjalankan program aplikasi. Berdasarkan data dari IDC (International Data Corparation) menunjukan bahwa pasar smartphone di seluruh dunia bertumbuh $27,2 \%$ pada tahun 2014 dengan 335 juta unit perangkat. Pengiriman perangkat android menempati urutan pertama di pasar dunia dengan 283 juta unit perangkat yang terkirim dan lebih dari $84 \%$ pangsa pasar pada kuartal ketiga tahun 2014. Hal ini dikarenakan permintaan konsumen yang meningkat. Hal ini menunjukan bahwa android diminati oleh pengguna di seluruh dunia. Faktor ini menjadi alasan untuk membuat aplikasi pada platform android. Pada penelitian kali ini peneliti akan membua aplikasi Panduan pola hidup sehat untuk perangkat mobile khususnya smartphone yang berbasis android. Sehingga hanya dengan menggunakan smartphone, pengguna dapat mempermudah untuk melakukan pola hidup sehat dan mengatur asupan kalori tanpa membeli buku atau berkonsultasi ke ahli kesehatan. Hal ini tentu saja dapat menjadi alat bantu didalam mengatur pola hidup sehatnya. Tahapan yang dilakukan untuk menjalankan proses pembangunan aplikasi tersebut meliputi tahapan analisis permasalahan dan kebutuhan, perancangan aplikasi dan desain interface, sehingga aplikasi yang terbentuk menjadi mudah untuk digunakan. Dari hasil uji coba terbukti bahwa aplikasi pola hidup sehat dapat memberikan informasi dan kemudahan pada beberapa orang dalam mengatur pola hidupnya.

Kata kunci: Android, Pola Hidup sehat, Smartphone.

\section{A. PENDAHULUAN}

Pola hidup sehat yang sesuai akan membantu untuk lebih sehat dan jauh dari penyakit. Kemajuan dunia seperti di Negara berkembang banyak menimbulkan perubahan pada pola hidup manusia. Apalagi saat ini sudah banyak makanan yang serba cepat atau instant. Kesibukan yang dihadapi oleh setiap orang menyebabkan mereka mengabaikan pola hidup mereka. Tetapi seharusnya melakukan hidup sehat itu penting untuk kita semua. Sebagian masyarakat menganggap remeh masalah menerapkan pola hidup sehat, sehingga banyak penyakit yang kapan pun dapat menyerang mereka. Sebagai contoh yang dapat kita ambil 
adalah lingkungan sekitar yang kurang bersih, tidak melakukan olahraga yang cukup buat ketahanan fisik, minum-minuman yang beralkohol dan kurangnya mengkonsumsi makanan yang bergizi. Bila kita ketahui banyak sekali dampak negatif tidak melakukan pola hidup sehat. Maka dari itu biasakan menerapkan pola hidup sehat dalam kehidupan sehari-hari. Dengan adanya panduan-panduan hidup sehat kita bisa melakukan gaya hidup sehat dalam kehidupan sehari-hari, baik dari makanan, minuman, tubuh maupun lingkungan, agar kita terhindar dari penyakit-penyakit yang berbahaya. Kemajuan

Teknologi di bidang telepon seluler semakin pesat. Di masyarakat sekarang ini, memiliki telepon seluler seakan telah menjadi kebutuhan pokok. Beragam aplikasi diciptakan untuk memudahkan aktifitas manusia. Banyak hal yang dapat dilakukan hanya dengan telepon seluler, mulai dari komunikasi sarana hiburan, manajemen, multimedia, dan lainnya. Setiap telepon seluler memiliki sistem operasi untuk menjalankan program aplikasi. Menurut Open Handset Alliance, "Android adalah sistem operasi yang di rancang khusus untuk perangkat seluler layar sentuh seperti tablet, telepon seluler pintar, PDA (Personal Digital Assistant) dan peralatan mobile lain. Sistem operasi android bersifat open source dimana pengembangan aplikasinya secara bebas dan gratis. Bermacam-macam jenis aplikasi tersedia di android sehingga dapat memenuhi kebutuhan pengguna".

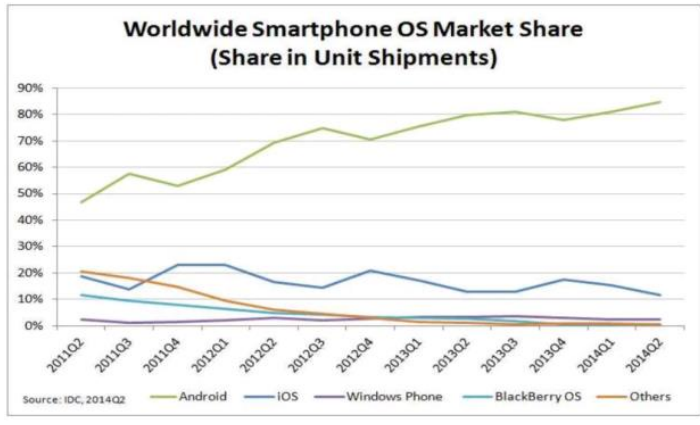

Gambar 1. Grafik Sistem Operasi di Dunia (Internal Data Corporation)

Berdasarkan data dari IDC (International Data Corparation) menunjukan bahwa pasar smartphone di seluruh dunia bertumbuh 27,2\% pada tahun 2014 dengan 335 juta unit perangkat. Pengiriman perangkat android menempati urutan pertama di pasar dunia dengan 283 juta unit perangkat yang terkirim dan lebih dari $84 \%$ pangsa pasar pada kuartal ketiga tahun 2014. Hal ini dikarenakan permintaan konsumen yang meningkat. Hal ini menunjukan bahwa android diminati oleh pengguna di seluruh dunia. Faktor ini menjadi alasan untuk membuat aplikasi pada platform android. Bermacam-macam genre aplikasi terdapat di telepon seluler, salah satunya adalah aplikasi dengan genre healthcare. Sebelum berkembangnya teknologi, orang umumnya mengunjungi ahli kesehatan dan membeli buku atau majalah tentang kesehatan. Sekarang dengan berkembangnya teknologi hal tersebut dapat di peroleh dari sebuah aplikasi. Sebuah aplikasi yang dapat membantu seseorang untuk melakukan pola hidup yang sehat.

\section{B. TINJAUAN PUSTAKA}

\section{Program}

Menurut (Maarif et al., 2017) "Program adalah rancangan mengenai asas serta usaha (dalam ketatanegaraan, perekonomian) yang akan dijalankan. Sedangkan program komputer yaitu urutan yang diberikan pada komputer untuk fungsi tugas tertentu".

Sedangkan menurut (Sari, 2017) "programming language (bahasa pemrograman) "merupakan suatu sintak untuk mendefinisikan program komputer, bahasa ini memungkinkan seorang programmer dapat membuat suatu program aplikasi”.

\section{Aplikasi}

Menurut (Marsa \& Sardiarinto, 2013), "Aplikasi adalah penggunaan dan penerapan suatu konsep yang menjadi suatu pokok pembahasan. Aplikasi dapat diartikan juga sebagai program komputer yang dibuat untuk menolong manusia dalam melakukan tugas tertentu". 
Menurut (Syamsul Rizal, Eko Retnadi, 2014), "Aplikasi adalah penggunaan dalam suatu perangkat komputer, instruksi (instruction) atau pernyataan (statement) yang disusun hingga sedemikian rupa komputer dapat memproses masukan (input) menjadi keluaran (output)".

Sedangkan menurut (Hidayatulloh \& AMIK, 2015), "Perangkat lunak aplikasi yaitu perangkat lunak yang digunakan untuk membantu pemakai komputer untuk melaksanakan pekerjaannya".

Dari beberapa pendapat diatas, dapat disimpulkan bahwa aplikasi adalah sebuah program atau perangkat lunak yang dirancang atau dibuat untuk tujuan tertentu dengan melakukan aktifitas tertentu melalui proses dan prosedur aliran data dalam infrastruktur teknologi informasi yang sesuai dengan jenjang dan kebutuhan.

\section{Android}

Menurut ( et al., 2016) "Android merupakan suatu software (perangkat lunak) yang digunakan pada mobile device (perangkat berjalan) yang meliputi sistem operasi, middleware dan aplikasi inti".

Menurut (Kuswanto \& Radiansah, 2018), "Android adalah sebuah sistem operasi untuk smartphone dan tablet. Sistem operasi dapat diilustrasikan sebagai jembatan antara piranti (device) dan penggunaannya, sehingga pengguna dapat berinteraksi dengan device-nya dan menjalankan aplikasi-aplikasi yang tersedia pada device."

\section{Flowchart}

Menurut (Nuraini, 2015), "Flowchart adalah mengembangkan aturan logika dari suatu prosedur pemecahan masalah, sehingga flowchart merupakan langkah-langkah penyelesaian masalah yang dituliskan dalam simbol tertentu".

\section{METODE PENELITIAN}

Penyusunan Metodologi pada penulisan laporan ini dimaksudkan agar laporan ini menjadi lebih terarah dan tersusun dengan baik.

1. Wawancara

Pada tahap ini penulis melakukan analisa kebutuhan dengan melakukan wawancara kepada ahli pakar kesehatan dan dari hasil wawancara di peroleh kebutuhan-kebutuhan yang diperlukan dalam pembuatan aplikasi mobile ini. Hal-hal yang dibutuhkan seputar pola hidup sehat baik dari panduan hidup seahat yang telah di anjurkan.

2. Studi Pustaka

Selain menggunakan metode di atas, teknik pengumpulan data juga dilakukan dengan studi pustaka. Metode ini dilakukan dengan cara mengumpulkan data dan informasi dengan membaca buku-buku, melakukan browsing di internet, dan mencari referensireferensi yang berkaitan dengan penulisan Laporan Tugas Akhir ini.

\section{HASIL DAN PEMBAHASAN}

Penerapan aplikasi ialah mengimplementasikan desain ke bentuk flowchart dan User Interface yang lebih menarik dilihat oleh pengguna aplikasi.

\section{Flowchart Program}

Menu utama adalah kumpulan dari semua menu-menu yang di tampilkan dalam aplikasi ini, menu tersebut terdiri dari menu pengertian pola hidup sehat, menu pola hidup sehat, menu gaya hidup tidak sehat, menu dampak-dampak, menu panduan pola hidup. 

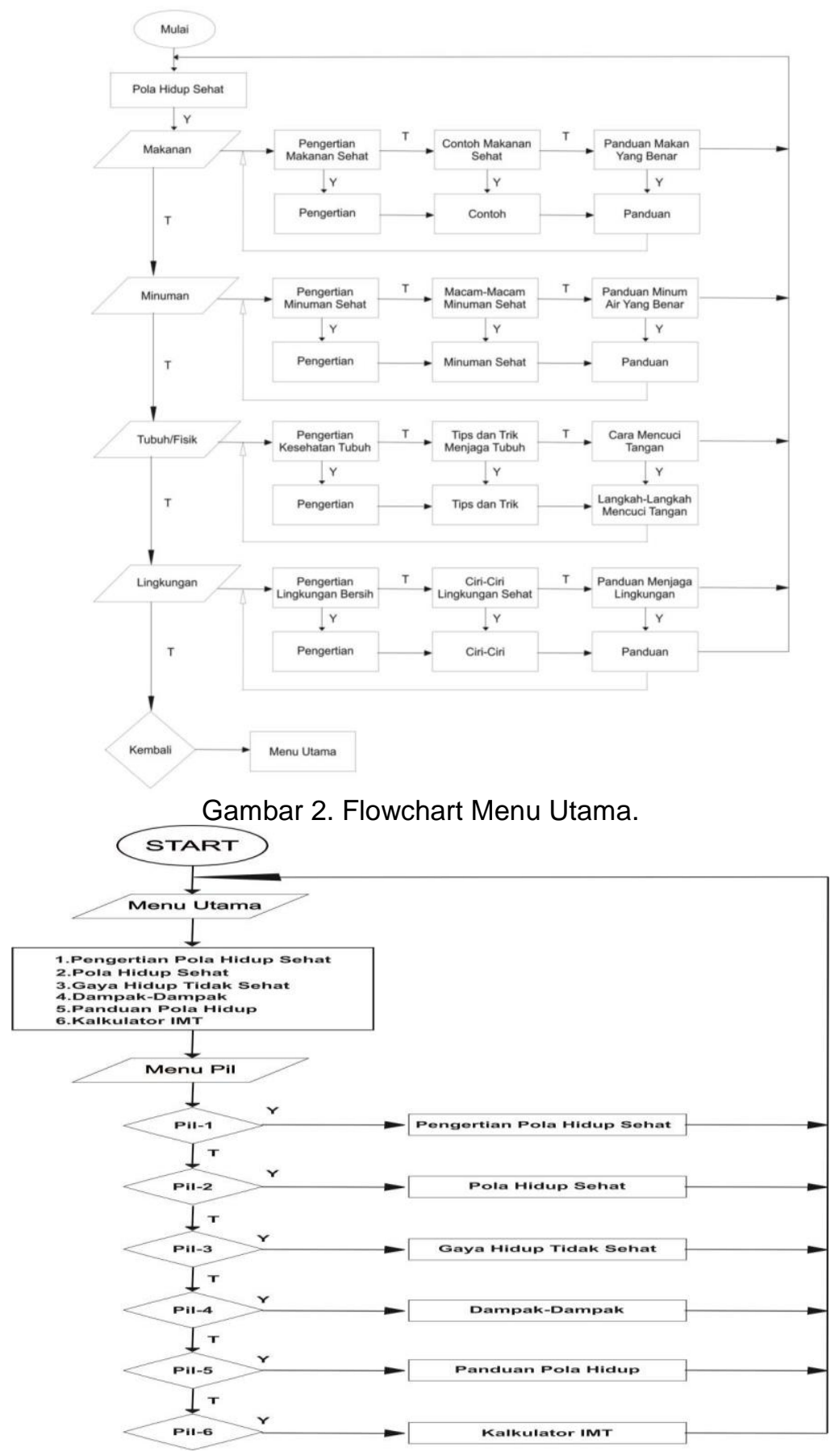

Gambar 2. Flowchart Menu Pola Hidup Sehat.

Menu pola hidup sehat merupakan menu yang berisi tentang panduan pola hidup sehat berdasarkan kategori seperti menu makanan, menu minuman, menu tubuh/fisik, menu lingkungan.

2. Implementasi

a. Layout Menu Utama 


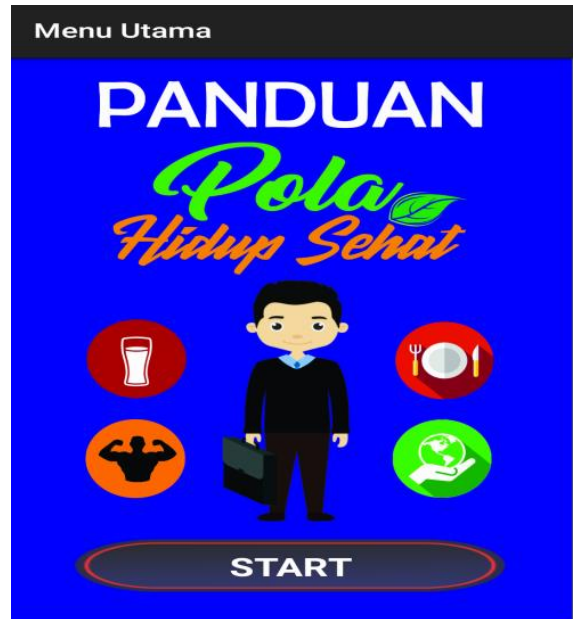

Gambar 3. Tampilan Halaman Menu Utama

Tampilan menu utama adalah tampilan dashboard aplikasi. Pada menu utama satu tombol untuk memulai aplikasi.

b. Layout Menu Home

Layout menu home adalah tampilan aplikasi untuk menampilkan menu makanan, menu minuman, menu tubuh/fisik, menu lingkungan.

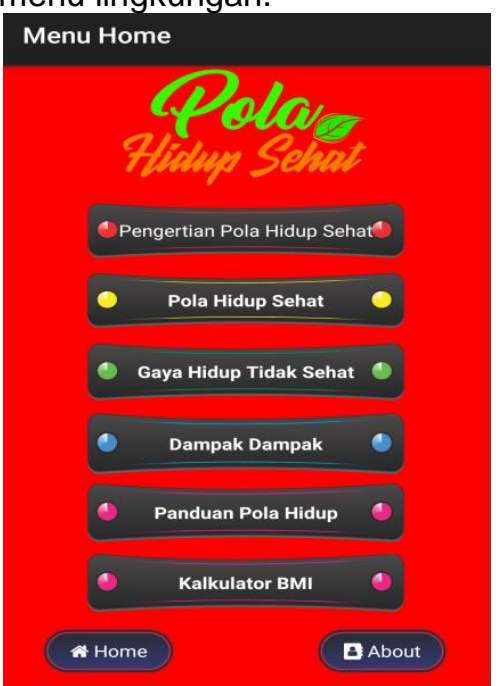

Gambar 4. Tampilan Halaman Menu Home

c. Layout Menu Panduan Pola Hidup

Layout menu panduan pola hidup adalah tampilan aplikasi untuk menampilkan panduanpanduan menjaga pola hidup yang lebih teratur. 


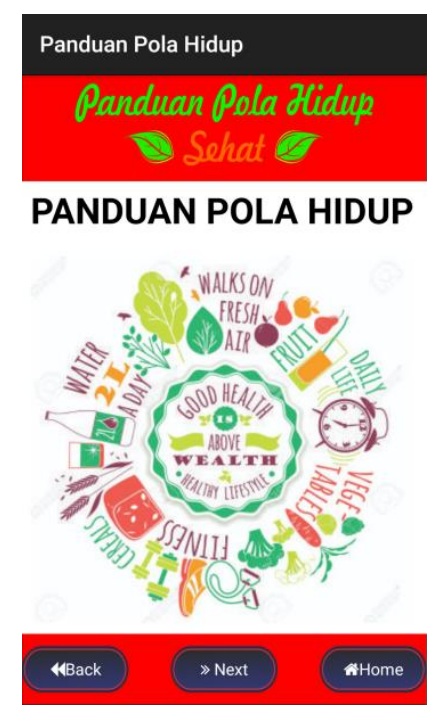

Gambar 5. Tampilan Halaman Menu Panduan Pola Hidup

d. Layout Menu Kalkulator IMT

Layout menu kalkulator IMT (Index Masa Tubuh) adalah tampilan aplikasi untuk menampilkan cara menghitung berat badan.

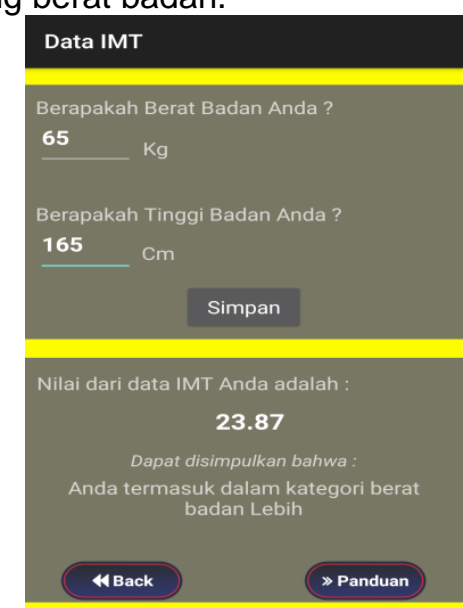

Gambar 6. Tampilan Halaman Menu Kalkulator IMT

\section{E. KESIMPULAN}

Berdasarkan uraian dan analisa dari bab sebelumya, maka dapat ditarik kesimpulan sebagai berikut:

1. Dalam aplikasi ini pengguna yang mempunyai masalah dalam melakukan pola hidup kurang sehat dapat membantu pengguna untuk lebih sadar akan kesehatan.

2. Aplikasi ini membahas tentang panduan pola hidup sehat, pengertian pola hidup sehat, gaya hidup tidak sehat, dampak positif dan dampak negatif pola hidup sehat serta kalkulator IMT (Indeks Masa Tubuh) untuk menghitung berat badan ideal pengguna.

3. Memudahkan pengguna aplikasi dalam berkonsultasi kesehatan tanpa harus membeli buku dan mendatangi ahli kesehatan.

4. Memudahkan pengguna aplikasi dalam menghitung berat badan ideal.

\section{REFERENSI}

Hidayatulloh, S., \& AMIK, C. M. (2015). Sistem Pelayanan Administrasi Kependudukan Desa Candigatak Berbasis Web. AMIK Cipta Darma Surakarta. 
Kuswanto, J., \& Radiansah, F. (2018). Media Pembelajaran Berbasis Android Pada Mata Pelajaran Sistem Operasi Jaringan Kelas XI. An Nabighoh Jurnal Pendidikan Dan Pembelajaran Bahasa Arab. https://doi.org/10.32332/an-nabighoh.v20i01.1131

Maarif, V., Widodo, A. E., \& Wibowo, D. Y. (2017). Aplikasi Tes IQ Berbasis Android. Ijse.Bsi.Ac.Id IJSE - Indonesian Journal on Software Engineering ISSN.

Marsa, D., \& Sardiarinto. (2013). Pengenalan Bahasa Inggris Untuk Anak Melalui Aplikasi Edukasi Berbasis Android. Seminar Nasional Teknologi Informasi Dan Komunikasi 2013 (SENTIKA 2013).

Nuraini, R. (2015). DESAIN ALGORITHMA OPERASI PERKALIAN MATRIKS MENGGUNAKAN METODE FLOWCHART. JURNAL TEKNIK KOMPUTER AMIK BSI.

Rahman, R. A., \& Tresnawati, D. (2016). Pengembangan Game Edukasi Pengenalan Nama Hewan dan Habitatnya Dalam 3 Bahasa Sebagai Media Pembelajaran Berbasis Multimedia. Jurnal Algoritma. https://doi.org/10.33364/algoritma/v.13-1.184

Sari, A. M. (2017). Aplikasi Situs Web Penjualan Hijab Online. Paradigma.

Syamsul Rizal, Eko Retnadi, A. I. (2014). Aplikasi Pencarian Obyek Wisata Terdekat di Kabupaten Garut Berbasis Android. Algoritma Sekolah Tinggi Teknologi Garut. 